\title{
NIEDOPEŁNIENIE OBOWIĄZKU REGULOWANIA SKLADEK CZLONKOWSKICH NA RZECZ SAMORZĄDU JAKO PODSTAWA ODPOWIEDZIALNOŚCI ZAWODOWEJ LEKARZA
}

\begin{abstract}
Streszczenie. W opracowaniu przedstawione zostały rozważania na temat ciążącego na lekarzu obowiązku opłacania składek członkowskich na rzecz samorządu zawodowego oraz konsekwencji niedopełnienia wskazanej powinności, jakie może ponieść przedstawiciel tej profesji w sferze odpowiedzialności zawodowej. Analiza podstaw prawnych prowadzenia postępowania $\mathrm{w}$ przedmiocie odpowiedzialności zawodowej za tego rodzaju przewinienie ukazana została na tle postanowienia SN z dnia 11 lutego 2016 r. (SDI 71/15) oraz w odniesieniu do zbliżonych rozwiązań, funkcjonujących na gruncie innych (wybranych) zawodów zaufania publicznego, których wykonywanie wiąże się z obligatoryjną przynależnością do samorządu i partycypowaniem w jego finansowaniu.
\end{abstract}

Słowa kluczowe: zawód lekarza, odpowiedzialność zawodowa, samorząd zawodowy, przewinienie zawodowe, składka członkowska, odpowiedzialność dyscyplinarna.

\section{WPROWADZENIE}

Za cel niniejszego opracowania postawiono sobie identyfikację źródła obowiązku opłacania składek członkowskich na rzecz samorządu zawodowego lekarzy $^{1}$ oraz ocenę dostatecznej określoności wskazanej powinności. Rozwadze poddana została dopuszczalność przypisania lekarzowi odpowiedzialności zawodowej za niedopełnienie obowiązku regulowania stosownych należności, jak również kwestia prawidłowej kwalifikacji prawnej takiego czynu. Punktem wyjścia dla owych rozważań uczyniono stanowisko Sądu Najwyższego wyrażone w postanowieniu z dnia 11 lutego $2016 \mathrm{r}$. (SDI 71/15). Analiza podstaw prawnych prowadzenia postępowania $\mathrm{w}$ przedmiocie odpowiedzialności lekarza za tego rodzaju przewinienie zawodowe dokonana została w odniesieniu do analogicznych rozwiązań funkcjonujących na gruncie innych profesji, w których przewidziana jest instytucja obligatoryjnej składki korporacyjnej, takich jak adwokat, radca prawny, notariusz i komornik.

* Uniwersytet Łódzki, Wydział Prawa i Administracji, Katedra Prawa Karnego, aleksandra.m. dabek@gmail.com.

${ }^{1}$ Ilekroć w opracowaniu jest mowa o lekarzu bez bliższego określenia, rozumie się przez to również lekarza dentystę. 


\section{OBOWIĄZEK REGULOWANIA SKŁADKI CZŁONKOWSKIEJ NA RZECZ SAMORZĄDU LEKARSKIEGO W OCENIE SĄDU NAJWYŻSZEGO}

Kwestia odpowiedzialności zawodowej lekarza za niedopełnienie obowiązku opłacania składki samorządowej nie została obszernie omówiona w orzecznictwie, jako że w przedmiocie tym Sąd Najwyższy, będący sądem kasacyjnym dla tej kategorii spraw, wypowiedział się jedynie w postanowieniu z dnia 11 lutego 2016 r. (SDI 71/15). Kanwą przywołanego orzeczenia stała się sprawa dwóch lekarzy, którym postawiony został zarzut popełnienia przewinienia zawodowego określonego w art. 59 zd. 1 Kodeksu Etyki Lekarskiej (dalej: KEL), polegającego na uchylaniu się od ,obowiązku wspierania samorządu zawodowego poprzez dobrowolne nieregulowanie obowiązkowych składek". Sprawa przekazana została do rozpoznania najwyższej instancji sądowej po wniesieniu kasacji od orzeczenia Naczelnego Sądu Lekarskiego (dalej: NSL), utrzymującego w mocy orzeczenie skazujące, wydane przez Okręgowy Sąd Lekarski (dalej: OSL). Sąd Najwyższy oddalił jednak kasację jako bezzasadną.

W tym miejscu warto przybliżyć zarzuty, jakie wskazani lekarze podnosili w toku kontroli instancyjnej. Od orzeczenia sądu pierwszej instancji obwinieni wnieśli wspólne odwołanie, w którym zarzucili, że OSL „utożsamił powinność wspierania działalności samorządu z przewinieniem zawodowym jako naruszeniem etyki lekarskiej, czego w istocie rzeczy nie dotyczą unormowania KEL" (post. SN nr SDI 71/15). Natomiast w skardze kasacyjnej, złożonej przez obrońcę jednego z obwinionych lekarzy, podniesiono m.in., że w toku przedmiotowego postępowania doszło do rażącego naruszenia przepisów, a mianowicie:

1) art. 63 pkt 1 i 2 ustawy z dnia 2 grudnia 2009 r. o izbach lekarskich (tekst jedn. Dz.U. z 2018 r., poz. 168; dalej: u.i.l.) - poprzez prowadzenie postępowania, pomimo iż zarzucony czyn nie zawiera znamion czynu zabronionego, jako że zarówno we wskazanej ustawie, jak i w KEL brak jest przepisu sankcjonującego nieregulowanie obowiązkowych składek;

2) art. 59 zd. $1 \mathrm{KEL}$ - poprzez nieprawidłowe uznanie, że nieregulowanie składek stanowi przewinienie zawodowe o znamionach określonych w tym przepisie, a w konsekwencji ukaranie obwinionego pomimo braku przesłanek prawnych do przypisania odpowiedzialności za taki czyn;

3) art. 89 ust. 2 pkt 1 i ust. 3 pkt 2 u.i.l. - poprzez brak wskazania kwalifikacji prawnej czynu oraz wobec niewskazania w uzasadnieniu orzeczenia faktycznej podstawy prawnej, jako że przywołany w orzeczeniu KEL nie stanowi aktu prawnego, a jego przepisy nie mogą być samodzielną podstawą wydania orzeczenia.

Odpowiadając na zarzut, po pierwsze - braku podstaw prawnych do prowadzenia postępowania $\mathrm{z}$ uwagi na brak przepisu sankcjonującego uchylanie się od uiszczania składki na rzecz samorządu lekarskiego, a po drugie 
- nieprawidłowego uznania tego rodzaju zaniechania za naruszenie zasad etyki zawodowej, Sąd Najwyższy wskazał, że KEL jest aktem wydanym w określonym przez ustawę trybie i przez organ ustawowo upoważniony, co przesądza o posiadaniu przez ten akt odpowiedniego statusu prawnego w ramach organizacji samorządu lekarskiego. Powinność poszanowania przez członków samorządu lekarskiego zasad etyki wypływa zaś z art. 8 u.i.l., która to jednocześnie w art. 5 pkt 1, art. 25 pkt 2 oraz art. 39 pkt 2 nakłada na władze tegoż samorządu obowiązek dbałości o ich przestrzeganie. Wreszcie - jak wynika z dalszej części uzasadnienia wyroku kasacyjnego - dochowywanie reguł wyrażonych w KEL gwarantowane jest przepisami art. 53-112 tej samej ustawy, normującymi odpowiedzialność zawodową za postępowanie sprzeczne z zasadami etyki lekarskiej. Ponadto - w ocenie Sądu Najwyższego - pomimo iż w uregulowaniach u.i.l. nie został wprost wyrażony obowiązek płacenia składki na rzecz samorządu, nie oznacza to, że powinność taka nie wynika z tejże ustawy. Zdaniem składu orzekającego świadczą o tym, co prawda pośrednio, przepisy art. 6 ust. 1, regulującego obowiązkową przynależność lekarza do samorządu, oraz art. 114 ust. 2, statuującego wpływy ze składek członkowskich wśród podstawowych źródeł finansowania samorządu, niezbędnych do wykonywania przez izby lekarskie swoich ustawowych zadań, niemniej ostatecznie kwestię tę przesądzają postanowienia uchwały Naczelnej Rady Lekarskiej (dalej: NRL) w sprawie wysokości składki członkowskiej². Skoro zatem - jak wywiódł Sąd Najwyższy - uchwała ta została podjęta w ramach upoważnienia ustawowego i dotyczy spraw samorządu lekarskiego, to zawinione zaniechanie przez lekarza, członka izby lekarskiej, płacenia składek członkowskich na rzecz samorządu stanowi czyn sprzeczny z zasadami etyki lekarskiej, co w konsekwencji wypełnia znamiona przewinienia zawodowego $\mathrm{w}$ rozumieniu art. 53 u.i.l. $\mathrm{W}$ tym kontekście nie można pominąć przywołania innego fragmentu uzasadnienia orzeczenia kasacyjnego, świadczącego o przychyleniu się Sądu Najwyższego do odmiennego z kolei stanowiska $\mathrm{w}$ kwestii znamion przewinienia zawodowego, wyczerpanych przez obwinionych lekarzy. Otóż sąd kasacyjny we wcześniejszej części rozważań uznał, że treść art. 8 u.i.l., zawierającego nakaz stosowania się nie tylko do zasad etyki lekarskiej, ale również do przepisów związanych z wykonywaniem zawodu i uchwał organów izb lekarskich, przemawia za przyjęciem na gruncie omawianej sprawy drugiej postaci przewinienia zawodowego, jaką jest naruszenie przepisów regulujących wykonywanie zawodu lekarza.

${ }^{2}$ Sąd Najwyższy powołuje się na uchwałę nr 8/08/V Naczelnej Rady Lekarskiej z dnia 4 kwietnia 2008 r. w sprawie wysokości składki członkowskiej, wydaną na podstawie art. 35 ust. 1 pkt 9 ówcześnie obowiązującej wersji u.i.l. Według aktualnego stanu prawnego kwestię tę reguluje uchwała Nr 27/14/VII Naczelnej Rady Lekarskiej z dnia 5 września 2014 r. w sprawie wysokości składki członkowskiej, wydana na podstawie art. 39 ust. 1 pkt 11 obecnie obowiązującej wersji u.i.l. 
Odnosząc się natomiast do zarzutu nieprawidłowego wskazania w sentencji orzeczenia kwalifikacji prawnej czynu, a w jego uzasadnieniu faktycznej podstawy prawnej, Sąd Najwyższy zgodził się ze stanowiskiem autora kasacji, że „kwalifikacja prawna czynu winna zawierać ustawową normę, która przewiduje odpowiedzialność za dany czyn lub zawierającą odniesienie do normy zawartej w innych przepisach”, niemniej jednocześnie uznał, że ,w przedmiotowej sprawie opis przypisanego obwinionemu deliktu dyscyplinarnego, w tym również w części związanej z jego kwalifikacją prawną, w zupełności spełnia te wymogi”, motywując swoje stanowisko faktem, iż ,obwiniony został uznany za winnego zarzucanego mu czynu, ze wskazaniem, że było to przewinienie zawodowe w ujęciu art. 59 zd. 1 KEL". Stąd - w ocenie sądu kasacyjnego - uznać należało, iż ,sentencja orzeczenia zawiera wyraźne ustalenie, że przewinienie to naruszało jedną z form deliktu dyscyplinarnego, określonego w art. 53 ustawy o izbach lekarskich, wobec naruszenia «zasad etyki lekarskiej», co stanowiło «przewinienie zawodowe»".

\section{PROBLEMY PRAWNE NA GRUNCIE ODPOWIEDZIALNOŚCI ZAWODOWEJ LEKARZA ZA NIEREGULOWANIE SKŁADEK CZLONKOWSKICH}

Analiza przywołanego orzeczenia prowadzi do wniosku, że w ocenianej sprawie pojawił się szereg wątpliwości, które jednak nie zostały dostatecznie wyjaśnione. W pierwszej kolejności nasuwa się pytanie o to, czy nakaz uiszczania składek na rzecz samorządu lekarskiego został w ogóle wyrażony w obowiązujących regulacjach, a jeśli nawet przyjąć odpowiedź twierdzącą, to czy został on wyartykułowany na tyle jasno, aby jego niewypełnienie mogło stanowić podstawę przypisania odpowiedzialności zawodowej. Wszak warto nadmienić, że pomimo iż odpowiedzialność zawodowa nie stanowi odpowiedzialności karnej sensu stricto, to jednak jest ona uznawana za jedną z odmian odpowiedzialności represyjnej, obok m.in. odpowiedzialności wykroczeniowej i odpowiedzialności dyscyplinarnej w zawodach prawniczych ${ }^{3}$. Przejawem quasi-penalnego charakteru postępowania w przedmiocie odpowiedzialności zawodowej lekarza jest w szczególności fakt, że poza karami upomnienia, nagany i karą pieniężną w reżimie tym mogą być wymierzane tak dotkliwe środki, jak zakaz pełnienia funkcji kierowniczych w jednostkach organizacyjnych ochrony zdrowia na okres od roku do pięciu lat, ograniczenie zakresu czynności w wykonywaniu zawodu lekarza na okres od sześciu miesięcy do dwóch lat, zawieszenie prawa wykonywania zawodu na okres od roku

${ }^{3}$ Zob. Buchała, Zoll (1997, 6), Szwarc (1999, 283), Bojańczyk (2004, 18-21), Bojańczyk (2017, 100 i n.), Gardocki (2006, 191), Kardas (2010, 109-112), Sroka (2011, 137 i n.), Sroka (2013, 3 i n.), Czarnecki (2013, 28-35). Szerzej na temat odrębności między postępowaniem karnym a postępowaniem w przedmiocie odpowiedzialności zawodowej: Zielińska (2001). 
do pięciu lat, a nawet pozbawienie prawa wykonywania zawodu. Stąd musi budzić zastrzeżenia brak wyraźnego ustawowego wyartykułowania obowiązku, którego naruszenie może skutkować odpowiedzialnością o charakterze sankcjonująco-dyscyplinującym. Wprawdzie skład orzekający zasygnalizował, że ów nakaz nie został wprost wyrażony w przepisach, a jedynie pośrednio wynika z szeregu różnej rangi regulacji, nie rozstrzygnął jednak, co konkretnie jest źródłem omawianej powinności, czy są to zasady etyki lekarskiej, przepisy związane z wykonywaniem zawodu lekarza, czy też może uchwały organów samorządu lekarskiego. Brak zaś takiego rozstrzygnięcia implikuje istotne konsekwencje w sferze prawidłowej konstrukcji orzeczenia skazującego, które zgodnie z art. 89 ust. 1 pkt 4 oraz art. 89 ust. 2 pkt 1 u.i.l. powinno zawierać dokładne określenie przypisanego obwinionemu czynu oraz jego kwalifikacji prawnej, a jego część motywacyjna również podstawę prawną orzeczenia. W przywołanym orzeczeniu kasacyjnym doskonale uwidaczniają się negatywne następstwa niewywiązania się składu orzekającego z zajęcia jasnego stanowiska w tej kwestii. Sąd Najwyższy nie wskazał bowiem - wobec, jak się wydaje, niepoczynienia wyczerpujących ustaleń - czy zarzucony czyn realizuje znamiona przewinienia zawodowego w postaci niedochowania zasad etyki lekarskiej czy też w formie naruszenia przepisów związanych z wykonywaniem zawodu lekarza, czy może z kolei w omawianej sprawie zachodzi potrzeba przyjęcia łącznej kwalifikacji czynu. Nie rozstrzygnięto również, czy naruszenie postanowień uchwał organów samorządu lekarskiego należy potraktować jako niedochowanie zasad etyki lekarskiej, czy jednak winno być ono uznane za naruszenie przepisów związanych z wykonywaniem zawodu lekarza. Ponadto Sąd Najwyższy nie sformułował jasnego przekazu - w szczególności dla składów orzekających w kolejnych postępowaniach w przedmiocie odpowiedzialności zawodowej lekarza - co do tego, jak prawidłowo konstruować kwalifikację prawną czynu, zwłaszcza w orzeczeniach skazujących. W tym zakresie omawiane postanowienie należy ocenić jako niespójne. Pomimo bowiem potwierdzenia, iż KEL nie może stanowić samoistnej podstawy prawnej, Sąd Najwyższy nie wskazał kategorycznie, że przywołanie normy deontologicznej w kwalifikacji prawnej czynu jest postępowaniem nieprawidłowym. Wprawdzie z całokształtu zaprezentowanych rozważań można wnioskować, że sąd kasacyjny za podstawę odpowiedzialności zawodowej przyjął art. 53 u.i.l., a w konsekwencji, że to ten właśnie przepis powinien być przytoczony w sentencji. Niemniej jednoczesne uznanie przez Sąd Najwyższy orzeczenia pierwszoinstancyjnego za spełniające wymagania w tym względzie może sugerować, że wskazanie przepisu KEL w kwalifikacji prawnej czynu jest przez najwyższą instancję akceptowalne.

Próba pogłębienia analizy prawnej dokonanej przez skład orzekający przedstawiona zostanie w kolejnej części rozważań. 


\section{4. ŹRÓDŁO OBOWIĄZKU OPLACANIA SKŁADEK CZŁONKOWSKICH NA RZECZ SAMORZĄDU LEKARSKIEGO}

Obowiązek opłacania składek członkowskich na rzecz samorządu lekarskiego nie został wprost wyrażony w przepisach regulujących zasady wykonywania zawodu lekarza oraz odpowiedzialności zawodowej w tej profesji ${ }^{4}$, jak ma to miejsce chociażby w zawodach notariusza ${ }^{5} \mathrm{i}$ komornika ${ }^{6}$ albo też $\mathrm{w}$ zawodach pielęgniarki i położnej'. Z treści art. 5-5f oraz art. 7 ustawy z dnia 5 grudnia 1996 r. o zawodach lekarza i lekarza dentysty (tekst jedn. Dz.U. z 2017 r., poz. 125), normujących przyznawanie prawa wykonywania zawodu oraz art. 8 tejże ustawy, stanowiącego, że lekarz, który uzyskał prawo wykonywania zawodu, podlega wpisowi do rejestru prowadzonego przez właściwą okręgową radę lekarską, jak również z brzmienia art. 6 u.i.l., zgodnie z którym lekarz posiadający prawo wykonywania zawodu przyznane przez okręgową radę lekarską, zamierzający wykonywać zawód, zostaje równocześnie wpisany na listę członków tej izby lekarskiej, można wprawdzie wywieść obowiązek przynależności do samorządu lekarskiego ${ }^{8}$, niemniej do analogicznego wniosku nie można dojść w odniesieniu do powinności opłacania obligatoryjnej składki członkowskiej na rzecz tej organizacji, gdyż w przywołanych przepisach wyrażona została ona co najwyżej pośrednio. Nakaz ten nie został jasno wyartykułowany także w przepisach art. 25 u.i.l., przyznających okręgowej radzie lekarskiej kompetencje do zbierania składek członkowskich i prowadzenia ich ewidencji, art. 27 tejże ustawy, stanowiącym, że wysokość składki członkowskiej określa prezes okręgowej izby lekarskiej, ani też art. 38 tej samej ustawy, zgodnie z którym Krajowy Zjazd Lekarzy ustala zasady podziału

${ }^{4}$ Zob. ustawę z dnia 5 grudnia 1996 r. o zawodach lekarza i lekarza dentysty (tekst jedn. Dz.U. z 2017 r., poz. 125), ustawę z dnia 15 kwietnia 2011 r. o działalności leczniczej (tekst jedn. Dz.U. z 2018 r., poz. 160) oraz u.i.1.

${ }^{5}$ Zob. art. 23 ustawy z dnia 14 lutego 1991 r. Prawo o notariacie (tekst jedn. Dz.U. z 2017 r., poz. 2291, dalej: p.n.), zgodnie z którym notariusze opłacają, na potrzeby organów samorządu notarialnego, składki miesięczne, których wysokość ustala corocznie Krajowa Rada Notarialna.

${ }^{6}$ Zob. art. 25 ustawy z dnia 29 sierpnia 1997 r. o komornikach sądowych i egzekucji (tekst jedn. Dz.U. z 2017 r., poz. 1277, dalej: u.k.s.e.), zgodnie z którym komornicy opłacają, na potrzeby organów samorządu komorniczego, składki miesięczne, których wysokość ustala corocznie Krajowa Rada Komornicza.

${ }^{7}$ Zob. art. 11 ustawy z dnia 1 lipca 2011 r. o samorządzie pielęgniarek i położnych (Dz.U. z 2011 r. Nr 174, poz. 1038, ze zm., dalej: u.s.p.p.) zgodnie z którym członkowie samorządu są obowiązani postępować zgodnie z zasadami etyki zawodowej oraz zasadami wykonywania zawodu określonymi w ustawie $\mathrm{z}$ dnia 15 lipca 2011 r. o zawodach pielęgniarki i położnej (tekst jedn. Dz.U. z 2018 r., poz. 123, dalej: u.z.p.p.), sumiennie wykonywać obowiązki zawodowe, przestrzegać uchwał organów izb, regularnie opłacać składkę członkowską oraz aktualizować dane w rejestrze pielęgniarek i rejestrze położnych.

${ }^{8}$ Zob. art. 40 ust. ustawy z dnia 6 lipca 1982 r. o radcach prawnych (tekst jedn. Dz.U. z 2017 r., poz. 1870 , dalej: u.r.p.), który jednoznacznie wskazuje, że przynależność radców prawnych i aplikantów radcowskich do samorządu jest obowiązkowa. 
składki członkowskiej. Również z art. 114 u.i.l., wskazującego, że majątek izb lekarskich powstaje m.in. ze składek członkowskich, oraz z następującego po nim art. 116, zgodnie z którym nieopłacone w terminie składki członkowskie i koszty postępowania w przedmiocie odpowiedzialności zawodowej lekarzy podlegają ściągnięciu w trybie przepisów o postępowaniu egzekucyjnym w administracji, jedynie pośrednio wynika obowiązek opłacania składki członkowskiej. Na marginesie właściwa organizacja procesu poboru, ewidencji i ustalania wysokości składek, choć niezaprzeczalnie istotna, wydaje się kwestią wtórną wobec samego obowiązku ich uiszczania, który to paradoksalnie nie został wyrażony w przepisach przytoczonych ustaw.

Należy dodać, że wyraźnego unormowania w tej kwestii nie zawiera również KEL, w przeciwieństwie do rozwiązań przyjętych przykładowo na gruncie zawodów adwokata ${ }^{9}$ radcy prawnego ${ }^{10}$. Źródła takiego obowiązku można dopatrywać się co najwyżej w treści art. 59 zd. 1 KEL, obligującego lekarzy do solidarnego wspierania działalności swojego samorządu, którego zadaniem jest zapewnienie lekarzom należytej pozycji w społeczeństwie. Wprawdzie przepis ten nawet odczytywany łącznie z art. $1 \mathrm{KEL}$, stanowiącym, że zasady etyki lekarskiej zobowiązują przedstawicieli tej profesji do dbania o godność zawodu, której zaś uchybieniem jest każde postępowanie lekarza, podważające zaufanie do zawodu lekarza, nie konkretyzuje, na czym ma polegać wspieranie działalności samorządu zawodowego. Niemniej jednak, biorąc pod uwagę zadania powierzone samorządowi lekarskiemu z mocy art. 5 u.i.l. oraz fakt, że nie wszystkie z nich finansowane są ze środków pochodzących z budżetu państwa - a jedynie wymienione w art. 115 ust. 1 tejże ustawy - można dojść do wniosku, że ,wspieranie działalności samorządu" przejawia się również we wsparciu finansowym. Zaś użyte w tym kontekście określenie „solidarnie” przemawia za przyjęciem stanowiska, że we wspomnianym wsparciu obowiązani są partycypować wszyscy członkowie samorządu, a w szczególności lekarze aktywni zawodowo.

Problematyka regulowania składek na rzecz samorządu zawodowego poruszona jest natomiast w uchwale Naczelnej Rady Lekarskiej z dnia 5 września 2014 r. w sprawie wysokości składki członkowskiej (uchw. nr 27/14/VII; dalej: uchwała NRL ws. wysokości składki członkowskiej), wydanej zgodnie z upoważnieniem

\footnotetext{
${ }^{9}$ Zob. § 65 Zbioru Zasad Etyki Adwokackiej i Godności Zawodu Adwokata (dalej: ZZEA), zgodnie z którym zawinione niepłacenie składki korporacyjnej stanowi poważne naruszenie zasad etyki zawodowej. Należy nadmienić, że ponadto na podstawie art. 44 ust. 3 ustawy z dnia 26 maja 1982 r. Prawo o adwokaturze (tekst jedn. Dz.U. z 2017 r., poz. 2368, dalej: p.a.), okręgowa rada adwokacka może zawiesić w czynnościach zawodowych, do czasu uiszczenia należności, adwokata, który zalega - pomimo wezwania - z zapłatą składki dłużej niż 6 miesięcy; zob. też: wyr. NSA z dnia 29 sierpnia 2017 r., II GSK 3308/15.

${ }^{10}$ Zob. § 66 Kodeks Etyki Radcy Prawnego (dalej: KERP), zgodnie z którym radca prawny obowiązany jest do terminowej zapłaty składki członkowskiej, składki na ubezpieczenie od odpowiedzialności cywilnej oraz opłat, kar pieniężnych, kosztów postępowania dyscyplinarnego i innych należności na rzecz samorządu radców prawnych.
} 
zawartym w art. 39 ust. 1 pkt 11 u.i.l. Na podstawie $\S 1$ tejże uchwały w odniesieniu do lekarza i lekarza dentysty, posiadających pełne prawo wykonywania zawodu, wysokość składki ustala się na 60 zł miesięcznie, natomiast lekarz stażysta, legitymujący się ograniczonym prawem wykonywania zawodu, opłaca składkę w wysokości 10 zł w skali miesiąca. Jak stanowi § 2 tej samej uchwały, obowiązek opłacania składki powstaje od pierwszego dnia miesiąca następującego po miesiącu, w którym lekarz albo lekarz stażysta został wpisany do rejestru członków okręgowej izby lekarskiej, albo utracił prawo do zwolnienia z obowiązku opłacania składki. Z kolei od zaległych składek nalicza się odsetki ustawowe od dnia wymagalności. Zwolnienie z obowiązku opłacania składki powstaje na podstawie przywołanej uchwały w pierwszym dniu miesiąca następującego po miesiącu, w którym lekarz ukończył 75 lat, został skreślony z rejestru członków okręgowej izby lekarskiej albo złożył oświadczenie, że nie osiąga przychodów z tytułu wykonywania zawodu.

W wyniku analizy przywołanych aktów prawnych i deontologicznych nasuwa się pytanie, jak prawidłowo sformułować zarzut w omawianej sprawie, skoro powinność uiszczania stosownych należności nie jest wyraźnie wyartykułowana ani w przepisach związanych $\mathrm{z}$ wykonywaniem zawodu, ani w KEL, a jedynie w uchwale organu izby lekarskiej, pośrednio natomiast wynika zarówno z owych przepisów, jak i z tegoż kodeksu. Zgodnie bowiem z art. 53 u.i.l., członkowie izb lekarskich podlegają odpowiedzialności zawodowej za przewinienia, które mogą polegać na niedochowaniu zasad etyki lekarskiej lub naruszeniu przepisów związanych z wykonywaniem zawodu lekarza ${ }^{11}$. Nie ulega wątpliwości, że prawidłowa subsumpcja powinna zostać poprzedzona precyzyjnymi ustaleniami, jakie znamiona przewinienia zawodowego wyczerpał czyn obwinionego lekarza. A mianowicie należy rozważyć, czy doszło do niedochowania zasad etyki zawodowej, czy też do naruszenia przepisów związanych z wykonywaniem zawodu, czy może zachodzi sytuacja, w której zachowanie lekarza wyczerpało jednocześnie znamiona obydwu postaci przewinienia zawodowego. W przypadku zaś uznania, że doszło do niedochowania zasad etyki zawodowej, winna zostać wskazana niedochowana norma deontologiczna. Natomiast, gdy zachowanie lekarza wyczerpuje znamiona naruszenia przepisów związanych z wykonywaniem zawodu, to należy wskazać konkretny przepis, który został przez lekarza naruszony. Sprawa nieco komplikuje się w sytuacji niezastosowania się przez

${ }^{11}$ Przepis wprawdzie posługuje się funktorem koniunkcji „oraz”, jednakże nie wydaje się, aby intencją ustawodawcy było penalizowanie tylko tych czynów, które łącznie spełniają obydwa warunki: niedochowania zasad etyki lekarskiej i naruszenia przepisów związanych z wykonywaniem zawodu lekarza. Stąd na potrzeby niniejszego opracowania autorka przyjmuje, że przepis należy odczytywać następująco: „Członkowie izb lekarskich podlegają odpowiedzialności zawodowej za naruszenie zasad etyki lekarskiej lub przepisów związanych z wykonywaniem zawodu lekarza, zwane dalej «przewinieniem zawodowym»”. W konsekwencji należy przyjąć, że na gruncie wskazanego przepisu możliwa jest także kumulatywna kwalifikacja prawna. 
lekarza do zasad wyrażonych w uchwale organu samorządowego, gdyż zgodnie z art. 8 u.i.l. członkowie izby lekarskiej są obowiązani dochowywać zasad etyki lekarskiej oraz przestrzegać przepisów związanych z wykonywaniem zawodu lekarza, a ponadto stosować się do uchwał organów izb lekarskich. A zatem tego rodzaju uchwały wyłączone zostały spośród ogółu przepisów związanych z wykonywaniem zawodu i włączone do odrębnej kategorii norm. Warto jednak ponownie odwołać się do KEL, którego art. 76 stanowi, że w przypadkach nie przewidzianych w tymże kodeksie należy kierować się zasadami wyrażonymi w uchwałach władz samorządu lekarskiego, w orzecznictwie sądów lekarskich oraz dobrymi obyczajami przyjętymi przez środowisko lekarskie. Można stąd wnioskować, że niezastosowanie się do uchwały rady lekarskiej należy uznać za niedochowanie zasad etyki zawodowej.

Jak się wydaje, powyższe przemawia za uznaniem zachowania, polegającego na zaniechaniu opłacania składek członkowskich na rzecz samorządu lekarskiego za przewinienie zawodowe w postaci niedochowania zasad deontologicznych. Jedynie bowiem w uchwale NRL ws. wysokości składki członkowskiej obowiązek regulowania tych należności został dostatecznie jasno wyrażony. Skoro zatem, zgodnie z KEL, niestosowanie się do uchwał samorządowych stanowi sprzeniewierzenie się zasadom etyki zawodowej, to właśnie tego rodzaju normy wypada uznać za źródło omawianego obowiązku, nie zaś przywołane przepisy prawa, z których nader trudno wyprowadzić normę nakazującą lekarzowi uiszczanie przedmiotowych składek ${ }^{12}$. Akcesoryjnie można również wskazać zasadę solidarności zawodowej, wyrażoną w art. 59 zd. 1 KEL oraz dobre obyczaje przyjęte przez środowisko lekarskie ${ }^{13}$, wspomniane w art. 76 tegoż kodeksu. Niemniej, w konsekwencji uznania za źródło obowiązku regulowania składek postanowień uchwały NRL ws. wysokości składki członkowskiej w związku z przepisami art. 59 i $76 \mathrm{KEL}$, do wyjaśnienia pozostaje kwestia prawidłowej kwalifikacji prawnej czynu, polegającego na niedochowaniu wskazanych reguł deontologii lekarskiej.

${ }^{12}$ Nieco odmienne stanowisko przyjął SN w omawianym postanowieniu dotyczącym zawodu lekarza, a także w uchw. z dnia 26 kwietnia 1990 r., III PZP 2/90, wyr. z dnia 24 kwietnia 1997 r., III SZ 1/97 oraz orzecz. z dnia 14 stycznia 1999 r., III SZ 3/98, które dotyczą zawodu radcy prawnego. W orzeczeniach tych SN wskazał, że obowiązek opłacania składek członkowskich nie wynika wprost z przepisów statuujących obowiązkową przynależność do samorządu zawodowego, jednakże powinność taką można z nich wywieść pośrednio. W konsekwencji SN doszedł do wniosku, że nieregulowanie stosownych należności może stanowić, poza niedochowaniem etyki zawodowej, również naruszenie przepisów związanych $\mathrm{z}$ wykonywaniem zawodu. W odniesieniu do zawodu radcy prawnego zob. też: post. SN z dnia 18 lipca 1985 r., I PA 20/85 oraz wyr. SN z dnia 12 grudnia 1997 r., III SZ 4/97.

${ }^{13}$ Zob. stanowisko Grzegorza Wrony, Naczelnego Rzecznika Odpowiedzialności Zawodowej, który wskazuje, że władze samorządu lekarskiego nie postulowały dotąd wpisania do ustaw i KEL obowiązku opłacania składek, gdyż przyjmowano, iż tym względzie członków samorządu lekarskiego łączy rodzaj umowy dżentelmeńskiej; tak: Wrona $(2016,30)$. 


\section{KWALIFIKACJA PRAWNA CZYNÓW POLEGAJĄCYCH NA NIEREGULOWANIU NALEŻNOŚCI NA RZECZ SAMORZĄDU ZAWODOWEGO}

Zgodnie z przepisami art. 89 ust. 1 pkt 4 oraz art. 89 ust. 2 pkt 1 u.i.l. orzeczenie sądu lekarskiego powinno zawierać przytoczenie opisu i kwalifikacji prawnej czynu, którego popełnienie rzecznik odpowiedzialności zawodowej zarzucił obwinionemu, zaś orzeczenie skazujące powinno ponadto zawierać dokładne określenie przypisanego obwinionemu czynu oraz jego kwalifikację prawną. Na gruncie omawianej sprawy pojawia się jednak problem, jaki przepis powinien znaleźć się w owej kwalifikacji, a konkretnie, czy może być to norma deontologii lekarskiej. W przedmiocie specyfiki norm etyki zawodowej niejednokrotnie wypowiadał się Trybunał Konstytucyjny ${ }^{14}$, wskazując, że normy deontologiczne nie posiadają charakteru prawnego, gdyż należą do niezależnego od prawa zbioru norm etycznych, i stąd nie mogą stanowić samoistnej podstawy prawnej. Niemniej jednak mogą one dookreślać normy prawne i w ten sposób zostać inkorporowane do systemu prawnego. Szczególną rolę pełnią one właśnie w procesie ustalania odpowiedzialności zawodowej. Przepisy statuujące przewinienia zawodowe mają bowiem w założeniu charakter blankietowy ${ }^{15}$. Oznacza to, że ogólnie sformułowana klauzula „przewinienia zawodowego" wymaga dopełnienia przez normy konkretyzujące, którymi w tego rodzaju reżimach odpowiedzialności są zwykle normy deontologiczne. Jak wielokrotnie wskazywał Trybunał Konstytucyjny ${ }^{16}$, ze względu na obiektywną niemożność stworzenia pełnego katalogu zachowań, które zagrażają należytemu wykonywaniu zawodu, precyzyjna typizacja deliktów dyscyplinarnych nie jest możliwa, a zatem w założeniu pozostają one ustawowo niedookreślone ${ }^{17}$. Do konkretyzacji znamion czynu, który zabroniony jest przez przepis o charakterze blankietowym, dochodzi poprzez odwołanie się do norm wyrażonych w aktach pozaustawowych prawnych lub deontologicznych. Niemniej jednak to właśnie ów przepis blankietowy stanowi podstawę odpowiedzialności zawodowej lekarza albo też dyscyplinarnej w zawodach prawniczych, choć samoistnie nie określa treści konkretnego czynu zabronionego i dla przypisania odpowiedzialności musi być uzupełniony normą konkretyzującą. Stanowisko takie utrwaliło się w orzecznictwie Sądu Najwyższego w odniesieniu do odpowiedzialności dyscyplinarnej w wymiarze sprawiedliwości oraz zawodach prawniczych, co zostanie ukazane w kolejnych zdaniach niniejszych rozważań.

${ }^{14}$ Zob. post. TK z dnia 7 października 1992 r., U 1/92, uchw. TK z dnia 17 marca 1993 r., W 16/92 oraz wyr. TK z dnia 23 kwietnia 2008 r., SK 16/07.

${ }^{15}$ Szerzej na temat samej konstrukcji przepisów blankietowych: Dębski (1995, 107-132).

${ }^{16}$ Zob. wyroki TK: z dnia 27 lutego 2001 r., K 22/00; z dnia 11 września 2001 r., SK 17/00; z dnia 2 września 2008 r., K 35/06, dnia 29 czerwca 2010 r., P 28/09; z dnia 6 listopada 2012 r., K 21/11; z dnia 29 stycznia 2013 r., SK 28/11.

${ }^{17}$ Zob. Leoński (1959, 156-160), Kubiak (1995, 79), Kozielewicz (2006, 31), Sroka (2013, 8 i n.). 
Rozpoczynając od orzeczeń dotyczących zawodu sędziego, warto przywołać wyrok z dnia 23 stycznia 2008 r. (SNO 89/07), w którym Sąd Najwyższy wyraźnie podkreślił, że materialną podstawę odpowiedzialności dyscyplinarnej sędziego stanowi art. $107 \S 1$ ustawy z dnia 27 lipca 2001 r. Prawo o ustroju sądów powszechnych (tekst jedn. Dz.U. z 2018 r., poz. 23; dalej: p.u.s.p.) ${ }^{18}$. Stanowisko to Sąd Najwyższy podtrzymał w wyroku z dnia 8 kwietnia 2010 r., wyjaśniając, że

materialnoprawna podstawa przypisania odpowiedzialności dyscyplinarnej, tak jak każdej odpowiedzialności represyjnej, musi być zakotwiczona w przepisie rangi ustawowej, a jedynie ewentualnie uzupełniona o przepisy podustawowe albo zawarte w uchwałach organów korporacyjnych (SNO 12/10).

Z kolei w sprawie zakończonej wyrokiem z dnia 29 października 2009 r. (SDI 22/09) Sąd Najwyższy rozpatrywał problem prawidłowej kwalifikacji - analogiczny do przywołanej na wstępie sprawie obwinionych lekarzy - jednakże w odniesieniu do zawodu adwokata, któremu także postawiono zarzut przewinienia dyscyplinarnego z podaniem w kwalifikacji prawnej czynu przepisu kodeksu etyki. Jak zauważył Sąd Najwyższy,

kwalifikacja prawna czynu mu zarzucanego powinna zainteresować orzekające w sprawie sądy dyscyplinarne, skoro zakwalifikowano zarzucane obwinionemu zachowanie jako wypełniające jedynie znamiona przewinienia przewidzianego w przepisach Zbioru Zasad Etyki Adwokackiej i Godności Zawodu (ZZEA), podczas gdy wiadomym tym sądom być powinno, że materialną podstawą odpowiedzialności dyscyplinarnej o charakterze represyjnym jest przepis art. 80 ustawy [...] Prawo o adwokaturze ${ }^{19}$.

Jak podkreślił sąd kasacyjny, wprawdzie przepis ten ma charakter blankietowy, a więc samoistnie nie określa treści konkretnego przewinienia i dla przyjęcia odpowiedzialności dyscyplinarnej powinien być uzupełniony normą konkretyzującą, np. wskazaniem konkretnej zasady etyki adwokackiej, to jednak ten właśnie przepis jest podstawą odpowiedzialności dyscyplinarnej adwokatów, zaś uregulowania zawarte w ZZEA nie mogą stanowić samoistnej, materialnoprawnej podstawy odpowiedzialności dyscyplinarnej o charakterze represyjnym.

Odnośnie do odpowiedzialności dyscyplinarnej w zawodzie adwokata Sąd Najwyższy wypowiedział się ponownie w postanowieniu z dnia 15 lipca 2010 r. $^{20}$ W sprawie tej za podstawowy błąd sąd kasacyjny uznał to, że

Wyższy Sąd Dyscyplinarny Adwokatury nie dostrzegł, iż utrzymuje w mocy orzeczenie, w którym za samodzielną podstawę odpowiedzialności dyscyplinarnej uznano nie przepis

${ }^{18}$ „Za przewinienia służbowe, w tym za oczywistą i rażącą obrazę przepisów prawa i uchybienia godności urzędu (przewinienia dyscyplinarne), sędzia odpowiada dyscyplinarnie".

${ }^{19}$ Zob. art. 80 p.a., zgodnie z którym adwokaci podlegają odpowiedzialności dyscyplinarnej za postępowanie sprzeczne z prawem, zasadami etyki lub godnością zawodu bądź za naruszenie swych obowiązków zawodowych, jak również za niespełnienie obowiązku zawarcia umowy ubezpieczenia.

${ }^{20}$ Zob. Cieślak, Kanty (2012, 146-152) oraz Bodio (2012, 153-160). 
rangi ustawowej, ale przepis zamieszczony w akcie wewnętrznym, wydanym przez organ samorządu zawodowego adwokatury (SDI 12/10),

bowiem przepis ZZEA, który w prawomocnym orzeczeniu przyjęty został jako samodzielna podstawa prawna skazania, zamieszczony jest $\mathrm{w}$ akcie korporacyjnym, jaki stanowi uchwała Naczelnej Rady Adwokackiej. Jak podkreślił Sąd Najwyższy w kolejnych zdaniach części motywacyjnej postanowienia, przy docenieniu rangi uchwał organów samorządu zawodowego, z całą stanowczością stwierdzić należy, że przepis o takim charakterze nie może jednak stanowić materialnoprawnej podstawy odpowiedzialności o charakterze represyjnym, a więc także i odpowiedzialności dyscyplinarnej. Podstawę taką może stanowić jedynie przepis rangi ustawowej, a zatem - w odniesieniu do zawodu adwokata - musi być to przepis art. 80 p.a.

Analogiczny pogląd Sąd Najwyższy wyraził również w wyroku z dnia 6 listopada 2014 r. (SDI 32/14) ${ }^{21}$, tym razem w odniesieniu do zawodu radcy prawnego, w którym przypomniał, że podstawą odpowiedzialności dyscyplinarnej radcy prawnego musi być przepis art. 64 u.r.p. ${ }^{22}$ Jak podkreślił sąd kasacyjny, podstawa ta ma charakter blankietowy, a więc samodzielnie nie pozwala na ustalenie, czy określone zachowanie wypełnia ustawowe znamiona przewinienia dyscyplinarnego. Dla przyjęcia odpowiedzialności dyscyplinarnej radcy prawnego konieczne jest zatem nie tylko określenie, że z tą właśnie podstawą wiąże się odpowiedzialność dyscyplinarna obwinionego radcy prawnego, ale ponadto wskazanie konkretnej zasady uregulowanej w KERP. I odwrotnie, uregulowanie zawarte w KERP również nie może stanowić samoistnej, materialnoprawnej podstawy odpowiedzialności dyscyplinarnej o charakterze represyjnym. Konkludując, Sąd Najwyższy potwierdził swoje dotychczasowe stanowisko, zgodnie z którym materialnoprawna podstawa przypisania odpowiedzialności dyscyplinarnej za popełnienie czynu sprzecznego z zasadami etyki radcy prawnego, tak jak każdej odpowiedzialności represyjnej, musi mieć oparcie w przepisie rangi ustawowej, czyli - w odniesieniu do zawodu radcy prawnego - w art. 64 ust. 1 pkt 2 u.r.p., a uzupełniająco w przepisach zawartych w KERP. Stanowisko to powtórzył Sąd Najwyższy w wyroku z dnia 17 listopada 2015 r., dodając przy tym, że

uchwały jakichkolwiek organów samorządu zawodowego nie mogą stanowić materialnoprawnej podstawy odpowiedzialności o charakterze represyjnym, a więc także odpowiedzialności dyscyplinarnej radców prawnych, w ramach której - co szczególnie trzeba podkreślić - dopuszczalne jest wymierzenie obwinionemu uznanemu za winnego kary dyscyplinarnej przewyższającej pod względem dolegliwości niejeden przewidziany w kodeksie karnym środek reakcji karnej (SDI 44/15).

${ }^{21}$ Zob. Skowron (2015), Karcz-Kaczmarek, Maciejewski (2015), Bojańczyk (2015).

${ }^{22}$ Zgodnie $\mathrm{z}$ tym artykułem radcowie prawni podlegają odpowiedzialności dyscyplinarnej za postępowanie sprzeczne z prawem, zasadami etyki lub godnością zawodu bądź za naruszenie swych obowiązków zawodowych, jak również za niespełnienie obowiązku zawarcia umowy ubezpieczenia. 
W tym tonie Sąd Najwyższy odniósł się również do kwestii odpowiedzialności zawodowej notariusza, uznając w wyroku z dnia 8 czerwca 2009 r. (SDI 4/09) za zasadny pogląd, jaki wcześniej wyraził na gruncie art. $107 \S 1$ p.u.s.p., zgodnie z którym przepis ten stanowi materialną podstawę odpowiedzialności dyscyplinarnej sędziego. Jak wskazał sąd kasacyjny, pogląd ten ma odpowiednie zastosowanie przy interpretacji przepisu art. 50 p.n., określającego znamiona przewinienia dyscyplinarnego notariusza ${ }^{23}$.

Mając na uwadze powyższe, uzasadnionym jest przyjęcie, że w kwalifikacji prawnej orzeczenia skazującego, wydawanego w toku postępowania $\mathrm{w}$ przedmiocie odpowiedzialności zawodowej lekarza, należy wskazać art. 53 u.i.l. Tym samym należy zgodzić się ze stanowiskiem Antoniego Bojańczyka, który podkreśla, że

prawidłowa kwalifikacja prawna w postępowaniu dyscyplinarnym (w przedmiocie odpowiedzialności zawodowej lekarza) wymaga [...] wyraźnego wskazania podstawy ustawowej skazania, którą w każdym przypadku będzie art. 53 [...], niezależnie od innych przepisów wchodzących w rachubę jako konkretyzacja ogólnych znamion wskazanych w tym artykule (Bojańczyk 2017, 106-107).

Jak się wydaje, naruszone normy deontologii, jako że nie mogą stanowić samoistnej podstawy prawnej, powinny natomiast zostać przywołane w części motywacyjnej orzeczenia jako dopełnienie generalnych znamion przewinienia zawodowego, określonych we wskazanym przepisie ustawowym.

\section{WNIOSKI KOŃCOWE}

W wyniku analizy obecnie obowiązujących aktów prawnych regulujących zasady wykonywania zawodu lekarza i odpowiedzialności zawodowej w tej profesji oraz kluczowego aktu deontologii lekarskiej, jakim jest Kodeks Etyki Lekarskiej, nasuwa się wniosek, że obowiązek opłacania składek członkowskich na rzecz samorządu lekarskiego nie został w aktach tych wprost wyrażony. Zarówno bowiem z przepisów normujących proces przyznawania prawa wykonywania zawodu lekarza oraz wpisu na listę członków izby lekarskiej, jak i regulujących kwestię poboru, ewidencji i ustalania wysokości składek, ale także z ogólnie sformułowanej w art. 59 KEL zasady solidarności zawodowej co najwyżej pośrednio można wywieść nakaz wspierania samorządu zawodowego w postaci obligatoryjnych składek korporacyjnych. Jedynym dokumentem, w którym jasno wyartykułowano powinność uiszczania tego rodzaju należności jest uchwała NRL ws. wysokości składki członkowskiej. Fakt ten w konsekwencji skłania do przekonania,

${ }^{23}$ Notariusz odpowiada dyscyplinarnie m.in. za przewinienia zawodowe, w tym za oczywistą i rażącą obrazę przepisów prawnych, uchybienia powadze lub godności zawodu, jak również za niespełnienie obowiązku zawarcia umowy ubezpieczenia. 
że de lege lata źródłem obowiązku regulowania przez lekarza składek samorządowych jest właśnie owa uchwała. $Z$ racji posiadania przez nią statusu aktu deontologii lekarskiej naruszenie jej postanowień należy uznać za zrealizowanie znamion przewinienia zawodowego, o którym mowa w art. 53 u.i.l., w postaci niedochowania zasad etyki zawodowej. Przemawia za tym brzmienie art. 76 KEL, który stanowi, że w przypadkach nie przewidzianych w tymże kodeksie należy kierować się zasadami wyrażonymi w uchwałach władz samorządu lekarskiego. Właściwą kwalifikację czynu polegającego na zaniechaniu opłacania składek członkowskich stanowi zaś art. 53 u.i.l., który winien zostać przywołany w sentencji orzeczenia wraz z doprecyzowaniem w części motywacyjnej reguł deontologii lekarskiej naruszonych popełnionym czynem. W omawianej sytuacji powinna zostać wskazana przede wszystkim uchwała NRL ws. wysokości składki członkowskiej w związku $\mathrm{z}$ art. $76 \mathrm{KEL}$, nakazującym w przypadkach nie przewidzianych w KEL stosować zasady wyrażone w uchwałach władz samorządu lekarskiego, a także akcesoryjnie art. $59 \mathrm{KEL}$, wprowadzający zasadę solidarności zawodowej. Nie można zgodzić się natomiast z twierdzeniami wyrażonymi w uzasadnieniu do postanowienia SN z dnia 11 lutego 2016 r. (SDI 71/15), sprowadzającymi się do konstatacji, że niedopełnienie omawianego obowiązku może stanowić także drugą postać przewinienia zawodowego, jaką jest naruszenie przepisów regulujących wykonywanie zawodu lekarza. Zajęcie takiego stanowiska wymagałoby bowiem przytoczenia konkretnych przepisów, którym nie dochowano wierności poprzez niepłacenie składek, co wobec braku wyraźnego wyartykułowania omawianego obowiązku w przepisach prawa byłoby wręcz niemożliwe. Jak można sądzić, z tego względu nie wskazał ich sam skład orzekający, poprzestając jednie na zasygnalizowaniu tej kwestii w jednym $\mathrm{z}$ fragmentów uzasadnienia.

Oceniając problem z perspektywy de lege ferenda, warto zaproponować nowelizację stosownych przepisów na wzór rozwiązań przyjętych w innych zawodach zaufania publicznego, których wykonywanie wiąże się z przynależnością do samorządu i obligatoryjnym partycypowaniem w jego finansowaniu. Optymalnym rozwiązaniem byłoby wprowadzenie obowiązku opłacania składek członkowskich do ustawy korporacyjnej, jak ma to miejsce w przypadku takich profesji, jak notariusz i komornik, przy jednoczesnym pozostawieniu art. 53 u.i.l. w obecnym kształcie. Zarówno w ustawie Prawo o notariacie ${ }^{24}$, jak i w ustawie o komornikach sądowych i egzekucji ${ }^{25}$ zawarto przepisy jasno obligujące przedstawicieli

${ }^{24}$ Zob. art. 23 p.n., zgodnie z którym notariusze opłacają, na potrzeby organów samorządu notarialnego, składki miesięczne, których wysokość ustala corocznie Krajowa Rada Notarialna. Zob. też: art. 50 tejże ustawy, zgodnie z którym notariusz odpowiada dyscyplinarnie m.in za przewinienia zawodowe, w tym za oczywistą i rażącą obrazę przepisów prawnych, uchybienia powadze lub godności zawodu, jak również za niespełnienie obowiązku zawarcia umowy ubezpieczenia.

${ }^{25}$ Zob. art. 25 u.k.s.e., zgodnie z którym komornicy opłacają, na potrzeby organów samorządu komorniczego, składki miesięczne, których wysokość ustala corocznie Krajowa Rada Komornicza. Na marginesie warto zaznaczyć, że wadą rozwiązania przyjętego na gruncie tejże ustawy jest 
wskazanych zawodów do opłacania na potrzeby działalności swoich samorządów składek miesięcznych, których wysokość ustalana jest corocznie przez organy tych samorządów o zasięgu krajowym. Podobne rozwiązanie przyjęte zostało w zawodach pielęgniarki i położnej ${ }^{26}$. Akceptowalnym rozwiązaniem byłaby również regulacja nawiązująca do koncepcji przyjętej na gruncie zawodów adwokata i radcy prawnego, w odniesieniu do których obowiązek uiszczania składek korporacyjnych zawarty jest w kodeksach etyki zawodowej. Zgodnie bowiem z KERP radca prawny obowiązany jest do terminowej zapłaty składki członkowskiej ${ }^{27}$, natomiast w ZZEA wyraźnie wskazuje się, że zawinione niepłacenie składki korporacyjnej stanowi poważne naruszenie przez adwokata zasad etyki zawodowej ${ }^{28}$. W obu zaś przypadkach przestrzeganie zasad etyki zawodowej zabezpieczone jest ustawowo przewidzianymi sankcjami o charakterze dyscyplinarnym.

\section{BIBLIOGRAFIA}

Bodio, Joanna. 2012. „Glosa do wyroku Sądu Najwyższego z 15 lipca 2010 r., SDI 12/10”. Palestra 5-6: 153-160.

Bojańczyk, Antoni. 2004. „Z problematyki relacji między odpowiedzialnością dyscyplinarną i karną (na przykładzie odpowiedzialności dyscyplinarnej zawodów prawniczych)". Państwo i Prawo 9: 17-31.

brak przepisu wskazującego, jakie zachowania należy uznać za przewinienie zawodowe. Błąd ten koryguje ustawa z dnia 22 marca 2018 r. o komornikach sądowych (Dz.U. z 2018 r., poz. 771, akt oczekujący), która w art. 222 wprowadza katalog działań i zaniechań, za które komornik odpowiada dyscyplinarnie.

${ }^{26}$ Zob. art. 11 u.s.p.p., zgodnie z którym członkowie samorządu są obowiązani postępować zgodnie z zasadami etyki zawodowej oraz zasadami wykonywania zawodu określonymi w u.z.p.p., sumiennie wykonywać obowiązki zawodowe, przestrzegać uchwał organów izb, regularnie opłacać składkę członkowską oraz aktualizować dane w rejestrze pielęgniarek i rejestrze położnych. Zob. też: art. 36 ust. 1 u.s.p.p., zgodnie z którym członkowie samorządu podlegają odpowiedzialności zawodowej za naruszenie zasad etyki zawodowej lub przepisów dotyczących wykonywania zawodu.

${ }^{27}$ Zob. § 66 KERP, zgodnie z którym radca prawny obowiązany jest do terminowej zapłaty składki członkowskiej, składki na ubezpieczenie od odpowiedzialności cywilnej oraz opłat, kar pieniężnych, kosztów postępowania dyscyplinarnego i innych należności na rzecz samorządu radców prawnych. Zob. też: art. 64 ustawy z dnia 6 lipca 1982 r. o radcach prawnych (tekst jedn. Dz.U. z 2017 r., poz. 1870), zgodnie z którym radcowie prawni podlegają odpowiedzialności dyscyplinarnej za postępowanie sprzeczne z prawem, zasadami etyki lub godnością zawodu bądź za naruszenie swych obowiązków zawodowych, jak również za niespełnienie obowiązku zawarcia umowy ubezpieczenia.

${ }^{28}$ Zob. § 65 ZZEA oraz art. 80 p.a., zgodnie z którym adwokaci podlegają odpowiedzialności dyscyplinarnej za postępowanie sprzeczne z prawem, zasadami etyki lub godnością zawodu bądź za naruszenie swych obowiązków zawodowych, jak również za niespełnienie obowiązku zawarcia umowy ubezpieczenia. Należy nadmienić, że ponadto, na podstawie art. 44 ust. 3 tejże ustawy, okręgowa rada adwokacka może zawiesić w czynnościach zawodowych, do czasu uiszczenia należności, adwokata, który zalega - pomimo wezwania - z zapłatą składki dłużej niż sześć miesięcy. 
Bojańczyk, Antoni. 2015. „Glosa do wyroku SN z dnia 6 listopada 2014 r., SDI 32/14”. LEX/el nr 1541265.

Bojańczyk, Antoni. 2017. „O orzeczeniach skazujących w postępowaniu w przedmiocie odpowiedzialności zawodowej lekarzy i obowiązku płacenia składek członkowskich na rzecz samorządu zawodowego lekarzy - uwagi na tle postanowienia Sądu Najwyższego z dnia 11 lutego 2016 r. (sygn. SDI 71/15)". Prawo i Medycyna 1: 100-121.

Buchała, Kazimierz, Andrzej Zoll. 1997. Polskie prawo karne. Wyd. 2. Warszawa: Wydawnictwo Naukowe PWN.

Cieślak, Wojciech, Tomasz Kanty. 2012. „Glosa do wyroku Sądu Najwyższego z 15 lipca 2010 r., SDI 12/10". Palestra 5-6: 146-152.

Czarnecki, Paweł. 2013. Postępowanie dyscyplinarne wobec osób wykonujących prawnicze zawody zaufania publicznego. Warszawa: Wydawnictwo C.H. Beck.

Dębski, Ryszard. 1995. Pozaustawowe znamiona przestępstwa. O ustawowym charakterze norm prawa karnego i znamionach typu czynu zabronionego nie określonych w ustawie. Łódź: Wydawnictwo Uniwersytetu Łódzkiego.

Gardocki, Lech. 2006. „Prawnokarna problematyka sędziowskiej odpowiedzialności dyscyplinarnej”. W Przestępstwo - kara - polityka kryminalna. Problemy tworzenia i funkcjonowania prawa. Księga jubileuszowa z okazji 70. rocznicy urodzin Profesora Tomasza Kaczmarka. Red. Jacek Giezek. Kraków: Wolters Kluwer.

Karcz-Kaczmarek, Maria, Mariusz Maciejewski. 2015. „Glosa do wyroku SN z dnia 6 listopada 2014 r., SDI 32/14". LEX/el nr 1541265.

Kardas, Piotr. 2010. „Przewinienie dyscyplinarne o charakterze ciągłym”. Rejent 20: 88-128.

Kozielewicz, Wiesław. 2006. „Odpowiedzialność dyscyplinarna notariuszy - problematyka materialnoprawna i procesowa”. Rejent 9: 25-46.

Kubiak, Jacek. 1995. „Wokół idei kodeksu etyki zawodowej sędziów”. Palestra 3-4: 77-97.

Leoński, Zbigniew. 1959. Odpowiedzialność dyscyplinarna w prawie Polski Ludowej. Poznań: Państwowe Wydawnictwo Naukowe.

Skowron, Andrzej. 2015. „Glosa do wyroku SN z dnia 6 listopada 2014 r., SDI 32/14”. LEX/el nr 1541265 .

Sroka, Tomasz. 2011. „Przestępstwo jako przewinienie dyscyplinarne w perspektywie celów postępowania dyscyplinarnego wobec studentów". Czasopismo Prawa Karnego i Nauk Penalnych 1: 137-147.

Sroka, Tomasz. 2013. „Realizacja zasady określoności czynu zabronionego z art. 42 ust. 1 konstytucji na gruncie odpowiedzialności dyscyplinarnej”. Forum Prawnicze 6: 3-17.

Szwarc, Andrzej. 1999. „Karny charakter odpowiedzialności dyscyplinarnej w sporcie”. W Rozważania o prawie karnym. Księga pamiątkowa z okazji siedemdziesięciolecia urodzin Profesora Aleksandra Ratajczaka. Red. Andrzej Szwarc. Poznań: Wydawnictwo Poznańskie.

Wrona, Grzegorz. 2016. „Uiszczanie składek na rzecz samorządu”. Gazeta Lekarska 6-7: 30.

Zielińska, Eleonora. 2001. Odpowiedzialność zawodowa lekarza i jej stosunek do odpowiedzialności karnej. Warszawa: Liber.

\section{Akty prawne i deontologiczne}

Kodeks Etyki Lekarskiej. http://www.nil.org.pl/dokumenty/kodeks-etyki-lekarskiej [dostęp: 9.04.2018].

Kodeks Etyki Radcy Prawnego. http://kirp.pl/etyka-i-wykonywanie-zawodu/etyka/kodeks-etyki-radcy-prawnego/ [dostęp: 9.04.2018].

Uchwała nr 8/08/V Naczelnej Rady Lekarskiej z dnia 4 kwietnia 2008 r. w sprawie wysokości składki członkowskiej. http://www.nil.org.pl/_data/assets/pdf_file/0014/4046/ru0008-08-V. pdf [dostęp: 9.04.2018]. 
Uchwała nr 27/14/VII Naczelnej Rady Lekarskiej z dnia 5 września 2014 r. w sprawie wysokości składki członkowskiej. https://nil.org.pl/_data/assets/pdf_file/0008/97262/ru027-14-VII.pdf [dostęp: 9.04.2018].

Ustawa z dnia 26 maja 1982 r. Prawo o adwokaturze (tekst jedn. Dz.U. z 2017 r., poz. 2368).

Ustawa z dnia 6 lipca 1982 r. o radcach prawnych (tekst jedn. Dz.U. z 2017 r., poz. 1870).

Ustawa z dnia 14 lutego 1991 r. Prawo o notariacie (tekst jedn. Dz.U. z 2017 r., poz. 2291).

Ustawa z dnia 5 grudnia 1996 r. o zawodach lekarza i lekarza dentysty (tekst jedn. Dz.U. z 2017 r., poz. 125).

Ustawa z dnia 29 sierpnia 1997 r. o komornikach sądowych i egzekucji (tekst jedn. Dz.U. z 2017 r., poz. 1277).

Ustawa z dnia 27 lipca 2001 r. Prawo o ustroju sądów powszechnych (tekst jedn. Dz.U. z 2018 r., poz. 23).

Ustawa z dnia 2 grudnia 2009 r. o izbach lekarskich (tekst jedn. Dz.U. z 2018 r., poz. 168).

Ustawa z dnia 1 lipca 2011 r. o samorządzie pielęgniarek i położnych (Dz.U. z 2011 r. Nr 174, poz. 1038 , ze zm.).

Ustawa z dnia 15 lipca 2011 r. o zawodach pielęgniarki i położnej (tekst jedn. Dz.U. z 2018 r., poz. 123).

Ustawa z dnia 22 marca 2018 r. o komornikach sądowych (Dz.U. z 2018 r., poz. 771, akt oczekujący).

Zbiór Zasad Etyki Adwokackiej i Godności Zawodu Adwokata (Kodeks Etyki Adwokackiej). http:// www.nra.pl/dokumenty/2018.01.30_Kodeks_Etyki_Adwokackiej_tekst_ujednolicony.pdf [dostęp: 9.04.2018].

\section{Orzecznictwo}

Orzeczenie SN z dnia 14 stycznia 1999 r., III SZ 3/98, OSNP 2000, nr 10, poz. 410.

Postanowienie SN z dnia 18 lipca 1985 r., I PA 20/85, PiZS 1986, nr 1, poz. 69.

Postanowienie SN z dnia 15 lipca 2010 r., SDI 12/10, OSNKW 2011, nr 3, poz. 25.

Postanowienie SN z dnia 11 lutego 2016 r., SDI 71/15, OSNKW 2016, nr 5, poz. 34.

Postanowienie TK z dnia 7 października 1992 r., U 1/92, OTK 1992, nr 2, poz. 38.

Uchwała SN z dnia 26 kwietnia 1990 r., III PZP 2/90, OSNC 1990, nr 12, poz. 142.

Uchwała TK z dnia 17 marca 1993 r., W 16/92, OTK 1993, nr 1, poz. 16.

Wyrok NSA z dnia 29 sierpnia 2017 r., II GSK 3308/15, LEX nr 2381092.

Wyrok SN z dnia 24 kwietnia 1997 r., III SZ 1/97, OSNP 1998, nr 4, poz. 139.

Wyrok SN z dnia 12 grudnia 1997 r., III SZ 4/97, OSNP 1999, nr 5, poz. 190.

Wyrok SN z dnia 23 stycznia 2008 r., SNO 89/07, OSNKW 2008, nr 5, poz. 37.

Wyrok SN z dnia 8 czerwca 2009 r., SDI 4/09, LEX nr 611833.

Wyrok SN z dnia 29 października 2009 r., SDI 22/09, LEX nr 1615502.

Wyrok SN z dnia 8 kwietnia 2010 r., SNO 12/10. http://www.sn.pl/sites/orzecznictwo/Orzeczenia1/

SNO\%2012-10.pdf [dostęp: 9.04.2018].

Wyrok SN z dnia 6 listopada 2014 r., SDI 32/14, OSP 2015, nr 7-8, poz. 80.

Wyrok SN z dnia 17 listopada 2015 r., SDI 44/15, LEX nr 1923851.

Wyrok TK z dnia 27 lutego 2001 r., K 22/00, OTK 2001, nr 3, poz. 48.

Wyrok TK z dnia 11 września 2001 r., SK 17/00, OTK 2001, nr 6, poz. 165.

Wyrok TK z dnia 23 kwietnia 2008 r., SK 16/07, OTK-A 2008, nr 3, poz. 45.

Wyrok TK z dnia 2 września 2008 r., K 35/06, OTK-A 2008, nr 7, poz. 120.

Wyrok TK dnia 29 czerwca 2010 r., P 28/09, OTK-A 2010, nr 5, poz. 52.

Wyrok TK z dnia 6 listopada 2012 r., K 21/11, OTK-A 2012, nr 10, poz. 119.

Wyrok TK z dnia 29 stycznia 2013 r., SK 28/11, OTK-A 2013, nr 1, poz. 5. 
Aleksandra Dąbek

\title{
FAILURE TO FULFILL THE OBLIGATION TO PAY A MEMBERSHIP FEE FOR THE SELF-GOVERNMENT AS THE BASIS OF THE PHYSICIAN'S PROFESSIONAL LIABILITY
}

\begin{abstract}
The article presents considerations about the physician's obligation to pay membership fees for the professional self-government and the consequences of failure to fulfill the obligation that a representative of this profession may suffer in the sphere of professional liability. The analysis of the legal grounds for conducting proceedings in terms of professional liability for this type of the offence was presented against the Supreme Court order of February 11, 2016 (SDI 71/15) and in relation to similar solutions operating in other (selected) groups of public trust professions, performance of which is connected with an obligatory membership in a self-government and participation in its financing.
\end{abstract}

Keywords: medical profession, professional liability, professional self-government, professional misconduct, membership fee, disciplinary liability. 